\title{
Comparative Study: Penggunaan Media Sosial oleh Pemerintah Kota Bandung dan Kota Gold Coast
}

\author{
Tengku Imam Syarifuddin ${ }^{1}$, Eko Priyo Purnomo ${ }^{2 *}$, Budiman $^{3}$, A.Andika Yasa ${ }^{4}$ \\ ${ }^{1}$ Magister Ilmu Pemerintahan, Universitas Muhammadiyah Yogyakarta \\ ${ }^{2}$ Magister Ilmu Pemerintahan, Universitas Muhammadiyah Yogyakarta \\ ${ }^{3}$ Ilmu Pemerintahan, Universitas Mulawarman \\ ${ }^{4}$ Magister Ilmu Pemerintahan, Universitas Muhammadiyah Yogyakarta \\ *Korespondensi: eko@mail.umy.ac.id
}

\begin{abstract}
This study aims to see how the city government which applies the concept of smart city utilizes social media platforms. The case taken is the twitter account of the Gold Coast City Council and the Bandung City Government. This research is a qualitative descriptive study using NVivo 12 Plus software as an analysis tool. The data used comes from the official twitter account @cityofgoldcoast belonging to the Gold Coast City Council and the @ humasbdg account belonging to the Bandung City Government. The results of this study are that the two accounts have similarities in terms of information delivery and interaction patterns. The two accounts in submitting the information were not complete, but instead included a link connected to the official government website. Furthermore, the two accounts carried out a one-way interaction pattern. The difference between the two accounts lies in the topic of discussion in each account and the distribution of information. The @ cityofgoldcoast account tends to tweet about actual conditions that are happening. Unlike the @humasbdg account which has discussion topics about protocol. In addition, both accounts have a distribution of information that adapts to the interactions they have made. At the end, the authors provide notes related to further research from this research.
\end{abstract}

Kata kunci: Compararive Study, Social Media, Gold Coast, Bandung

\begin{abstract}
ABSTRAK
Penelitian ini bertujuan untuk meliahat bagaimana pemerintah pada kota yang menerapkan konsep smart city memanfaatkan platform media sosisal. Kasus yang diambil adalah akun twitter Majelis Kota Gold Coast dan Pemerintah Kota Bandung. Penelitian ini merupakan penelitian deskriptif kualitatif dengan memanfaatkan software NVivo 12 Plus sebagai alat analisis. Data yang digunakan berasal dari akun twitter resmi @cityofgoldcoast milik Majelis Kota Gold Coast dan akun @humasbdg milik Pemerintah Kota Bandung. Hasil dari penelitian ini adalah kedua akun tersebut memiliki kesamaan dalam hal penyampaian informasi dan pola interaksi. Kedua akun dalam menyampaikan informasi tidak secara lengkap, melainkan mencantumkan tautan yang terhubung ke website resmi pemerintah. Selanjutnya kedua akun melakukan pola interaksi yang hanya satu arah. Perbedaan kedua akun terletak pada topik pembahasan disetiap akun dan persebaran informasi. Akun @cityofgoldcoast cenderung mentweet terkait kondisi aktual yang terjadi. Berbeda dengan akun @ humasbdg yang memiliki topik pembahasan seputar keprotokoleran. Selain itu kedua akun memiliki persebaran informasi yang menyesuaikan dengan interaksi yg dilakukan. Diakhir penulis memberikan catatan terkait penelitian lanjutan dari pada penelitian ini.
\end{abstract}

Keywords: Comparative Study, Media Sosial, Gold Coast, Bandung

1 Penggunaan Media Sosial....... 


\section{PENDAHULUAN}

Perserikatan Bangsa-Bangsa menyebutkan bahwasanya lebih dari 50 persen populasi didunia hidup dan menetap di perkotaan, hal ini diperkirakan akan meningkat menjadi 75 persen pada tahun 2050 (SáezMartín, Haro-de-Rosario, \& Caba-Perez, 2014). Kemacetan lalu lintas, kepadatan penduduk, pengelolaan limbah, dan polusi adalah beberapa tantangan penting yang akan menjadi masalah wilayah perkotaan (Moreno-Ibarra \& Torres-Ruiz, 2019). Jadi, banyak perencana kota mempertimbangkan bagaimana membentuk kota masa depan dan bagaimana menggunakan sumber daya yang langka yang tersedia untuk meningkatkan kualitas hidup penduduk (Sáez-Martín et al., 2014). Hal ini didasarkan karena kompleksitas permasalah yang ada di perkotaan akan berpengaruh terhadap produktivitas serta kualitas kehidupan di perkotaan pula (Desdemoustier, Crutzen, \& Giffinger, 2019)

Inovasi di bidang teknologi informasi dan komunikasi (TIK) menawarkan peluang signifikan untuk mengatasi tantangan yang dihasilkan dari permasalahan yang muncul di perkotaan (Moreno-Ibarra \& TorresRuiz, 2019). Hal tersebut dapat ditemukan dalam berbagai konsep pembangunana "Smart city" atau dengan sebutan lain seperti sustainable city, intelligent city, knowledge city, creative city, innovative city, uniquitous city, digital city and city 2.0 (Sáez-Martín et al., 2014). Inisiatif kota cerdas berupaya memanfaatkan sumber daya manusia, sosial, dan teknis untuk memastikan bahwa manusia memiliki pembangunan berkelanjutan dan kualitas hidup (Alkhatib, El Barachi, \& Shaalan, 2019). Dhingra \& Chattopadhyay (2016) berpendapat untuk mencapai tujuan itu, kota pintar memanfaatkan kemampuan infrastruktur teknologi, populasi, dan institusi dan berputar di sekitar empat aspek utama: 1) Keberlanjutan; 2) Kualitas hidup; 3) Pembangunan perkotaan; dan 4) Kecerdasan teknologi.

Konsep smart city dalam pelaksanaan kebijakan menggunakan data bertujuan untuk meningkatkan pelayanan publik (Witanto, Lim, \& Atiquzzaman, 2018). Konsep ini merupakan kunci untuk survive di era big data (Gintova, 2019). Para ilmuan berpendapat bahwasannya media sosial berimplikasi dalam akuntabilitas, transparansi (Charalabidis, Loukis, Androutsopoulou, Karkaletsis, \& Triantafillou, 2014; Clarke, 2017; Gintova, 2019; Gunawong, 2014; Magro, 2013), partisipasi masyarakat (Belkahla Driss, Mellouli, \& Trabelsi, 2019; Charalabidis et al., 2014; Clarke, 2017; Gintova, 2019), dan meningkatkan pelayanan public (Charalabidis et al., 2014; Clarke \& Margetts, 2014; Gintova, 2019; Magro, 2013). Media sosial di pemerintah memiliki peran nyata dalam inovasi organisasi sektor public (Belkahla Driss et al., 2019; Criado, Sandoval-Almazan, \& Gil-Garcia, 2013).

Media sosial memungkinkan penelitian mengetahui perasaan dan ide orang tentang faktor-faktor yang mengganggu kegiatan sehari-hari mereka, pemerintah dan organisasi yang terlibat dalam meningkatkan kehidupan masyarakat dan menyelesaikan masalah khusus dengan informasi terbaru mereka (Moreno-Ibarra \& Torres-Ruiz, 2019). Dengan 
pertumbuhan yang cepat dan proliferasi platform media sosial, ada sejumlah besar konten yang dibuat pengguna yang dapat digunakan sebagai sumber informasi tentang kota (Alkhatib et al., 2019). Selanjutnya Gintova (2019) berpendapat bahwa media sosial merupakan teknologi yang membawa perubahan penting baru ke fokus yang berorientasi pada klien dalam pemberian layanan publik. Selain itu media sosial memberikan kemampuan kepada organisasi untuk mensurvei penilaian terhadap konten dan penilaian terkait dengan suatu peristiwa secara real time (Birjali, Beni-Hssane, \& Erritali, 2017; Witanto et al., 2018). Lebih jauh, media sosial mengubah cara orang berkomunikasi dengan pemerintah. Sekarang setiap pengguna media sosial dapat langsung mencari informasi, mempostingnya dan membuat konten mereka sendiri di platform media sosial pemerintah(Gintova, 2019).

Di Kanada, pemerintah federal, provinsi, dan kota membuat akun media sosial pada 2000-an dan sekarang menggunakannya untuk berinteraksi dengan public (Gintova, 2019). Contoh lain dari kasus ini adalah laporan lalu lintas yang diterbitkan di Twitter seperti@Trafico889 di Mexico City. Karena banyaknya pengguna yang dapat melaporkan acara secara bersamaan di media sosial (Alsonosy, Rady, Badr, \& Hashem, 2018). Lu \& Brelsford (2014) dalam penelitiannya menggunakan media sosial twitter sebagai kerangka kerja pendeteksian komunitas yang sistematis dalam bencana gempa bumi dan tsunami di jepang.

Clarke (2017) berpendapat bahwa media sosial menawarkan potensi interaksi pemerintah real-time dengan warga, serta meningkatkan minat dalam perilaku ekonomi atau memberikan "dorongan" untuk mengatasi masalah sosial dan gamifikasi. Dalam merancang algoritma, metode otomatis untuk analisis data, pemerintah akan terlibat dalam analisis data besar transaksional yang lebih kompleks yang sudah ada di kantong mereka. Dalam merancang algoritma, metode otomatis untuk analisis data, pemerintah akan terlibat dalam analisis data besar transaksional yang lebih kompleks yang sudah ada di kantong mereka. Selain "dorongan informasi" ini, para pembuat kebijakan juga beralih ke jejaring sosial untuk "mengumpulkan informasi," mengumpulkan data berskala besar, non-menengah, dan tidak terstruktur, mencatat persepsi dan aspirasi orang-orang yang ditemukan dalam interaksi online dan memberikan bukti lebih lanjut tentang proses pengembangan kebijakan dan menyediakan layanan berbasis kebijakan yang sensitif dalam kebijakan (Clarke, 2017; Clarke \& Margetts, 2014).

Pada penelitian ini penulis akan membandingkan sejauhmana Majelis Kota Gold Coast dan Pemerintah Kota Bandung memanfaatkan media sosial. Media sosial yang digunakan adalah twitter, hal ini didasarkan twitter dipandang sebagai sumber data baru karena menawarkan sudut pandang yang berbeda dari banyak pengguna dan topik yang berbeda seperti kesehatan, lingkungan, politik, ekonomi, olahraga, bencana alam, dan lainnya (Moreno-Ibarra \& Torres-Ruiz, 2019). Tulisan ini menggunakan pendekatan penelitian kualitatatif dengan pendekatan komparasi study, Objek penelitian yang akan dikomparasi adalah media sosial twitter@goldcoascity dan @HumasBdg. Kota Gold Coast dipilih dikarenakan pada 
tahun 2013, kota ini berpartisipasi pada IBM's smarter cities challenge untuk melibatkan TIK dalam segala kegiatan di kota (Alizadeh \& Irajifa, 2018; Gold Coast City Council, 2018). Sedangkan Pemerintah Kota Bandung dalam penelitian Nurmandi et al., (2018) memasukan TIK dalam kerangka organisasi pemerintah daerah yang bertujuan untuk meningkatkan efisiensi dan layanan publik mereka. Sehingga pembeda antara penelitian ini dan penelitian lainnya adalah dari segi subjek penelitian. Beberapa penelitian terdahulu memfokuskan kepada suatu bidang, dalam penelitian ini melihat subjek yang lebih luas.

\section{METODE}

Penelitian merupakan qualitative research dengan menggunakan pendekatan deskriptif. Penelitian kualitatif adalah konstruktivisme yang mengasumsikan bahwa realitas itu jamak, interaktif, dan pertukaran pengalaman sosial yang ditafsirkan oleh masing-masing individu (Walidin, Idris, \& Tabrani ZA, 2015). Selanjutnya studi literatur yang dilakukan oleh peneliti kualitatif, fungsinya dapat dilihat sebagai "alat" yang dapat menjawab pertanyaan; "apa maksud dari dokumen yang ditulis?; apa latar belakangnya?; apa yang bisa dokumen katakan kepada peneliti?; dalam keadaan apa dokumen itu ditulis?; dntuk siapa?" dll (Nilamsari, 2014).
Penelitian ini menggunakan perangkat lunak Nvivo 12 Plus sebagai alat bantu dalam menganalisis. Selanjutnya penulis menggunakan fitur capture yang berfungsi untuk menangkap konten yang berasal dari media sosial. Capture yang dapat dimasukkan adalah penangkapan yang dihasilkan fitur NCapture sebagai aplikasi Nvivo default yang diinstal secara otomatis di Google Chrome ketika menginstal NVivo. NCapture memudahkan untuk memperoleh data penelitian yang berkaitan dengan analisis konten media sosial, tanpa harus membaca dan menganalisis posting satu per satu.

\section{HASIL DAN PEMBAHASAN}

\section{Isi Hasil dan Pembahasan}

Kita hidup di abad ke-21, di mana penggunaan media sosial berkembang dari hari ke hari dan orang-orang menggunakan media sosial untuk penggunaan pribadi dan professional (Bhatti, Arif, Mehar, \& Younas, 2018). Penggunaan Twitter di Indonesia berpotensi sangat besar dan menunjukan jumlah yang signifikan, bahkan CEO Twitter sendiri mengatakan bahwa Indonesia sebenarnya memainkan peran sentral dalam perjalanan bisnis di Twitter (Susanto, 2017). Oleh karena itu, akun twitter memiliki peran yang cukup penting di era distrubsi dalam rangka percepatan penyampaian informasi kepada masyarakat. 


\section{Noken Vol.6 (No.1) Halaman: 75-90 Tahum}

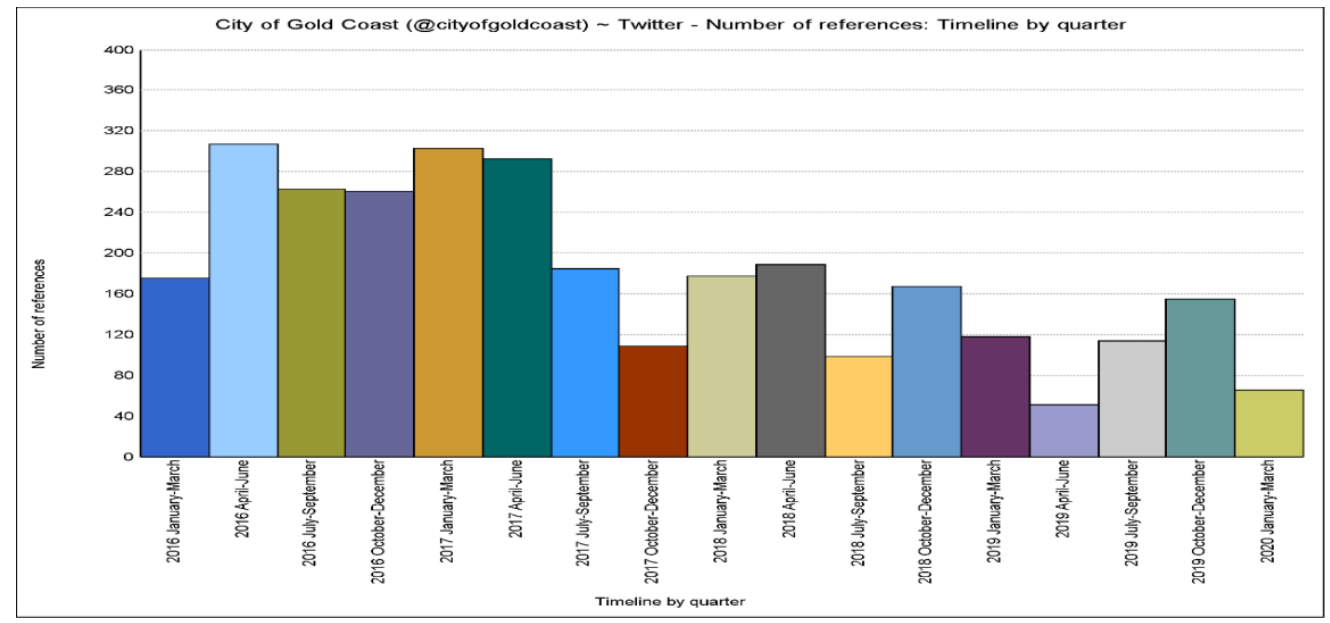

\section{Gambar 1}

Intensitas Tweet Akun @cityofgoaldcoast 2016-2020 (diolah oleh penulis, 2020)

Jika melihat gambar.1 data yang bersumber dari akun twitter milik Majelis Kota Gold Coast, tweet pertama dilakukan pada bualn januari tahun 2016. Rentan waktu paling besar dalam melakukan tweet terdapat pada bulan April-Juni 2016. Kecenderungan akun @cityofgoldcoast memposting konten lebih sering pada rentan waktu oktober-desember dan januari-maret. Jika ditelusuri lebih mendalam, pada bulan desember dan januari bertepatan dengan liburan natal dan tahun baru. Hal ini jelas berpengaruh kepada kepadatan informasi yang diberikan pemerintah melalui media sosial @cityofgoldcoast. Hal ini merupakan salah satu cara Majelis Kota Gold Coast memberikan pelayanan kepada masyarakat. Agar ketika melaksanakan aktivitas merasa terbantu dengan informasi yang update melalui media sosial twitter.

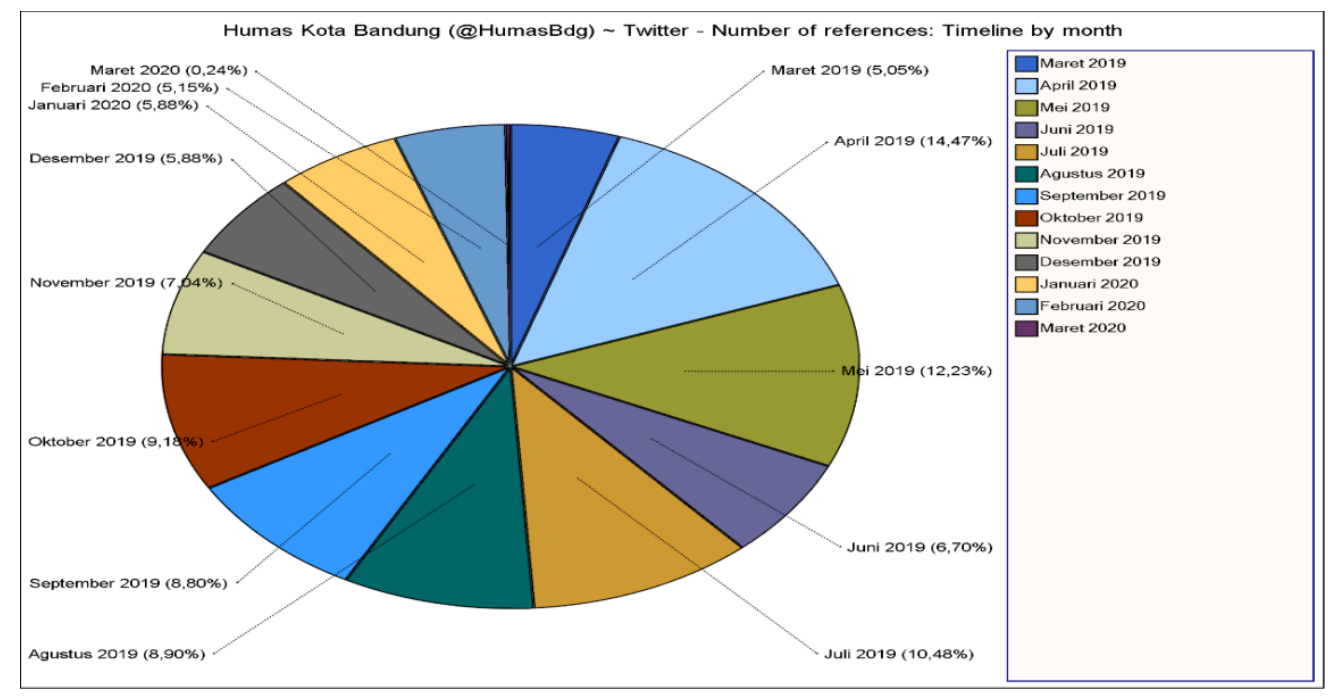

Gambar 2

Intensitas Tweet Akun @humasbdg Tahun 2019 - 2020 (diolah oleh penulis, 2020) 
Akun twitter@humasbdg milik Pemerintah Kota Bandung memiliki usia lebih muda daripada akun twiter milik Majelis Kota Gold Coast. Akun @ humasbdg pertama kali memposting pada bulan maret 2019. Tweet terbanyak dilakukan pada bulan april 2019 dengan jumlah 420 tweet. Penulis berspekulasi bahwasanya hal tersebut dipengaruhi oleh prestasi yang diraih oleh Pemerintah Kota Bandung pada bulan tersebut. Walikota Bandung mendapatkan penghargaan sebagai TOP Pembinaan BUMD dan Direktur Utama PDAM Kota Bandung meraih TOP CEO dalam ajang yang dilaksanakan oleh Majalah Top Business bekerjasama dengan Asia Business Research Center. Penghargaan selanjutnya adalah Best Innovation on Metropolitan and BIG Governance dan Best Wali Kota IIA. Penghargaan ini diberikan oleh Asosiasi Pemerintah Kota Seluruh
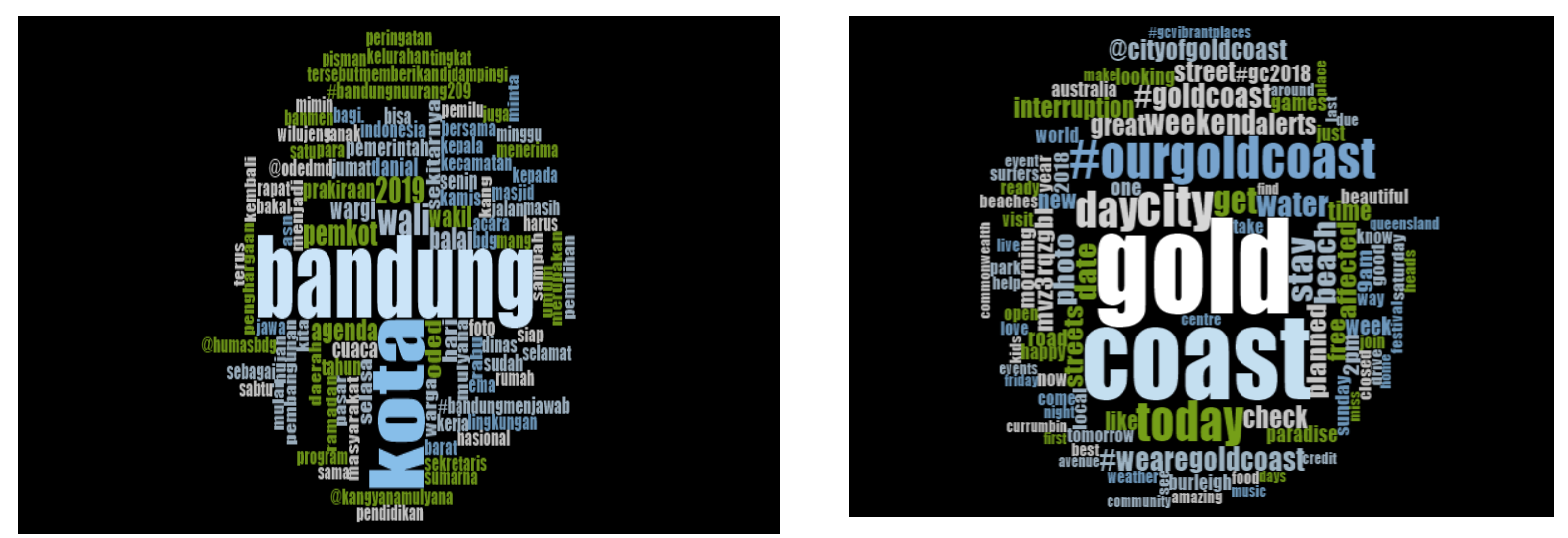

Gambar 3

Topik Pembicaraan Akun @ cityofgoldcoast dan @humasbdg (diolah oleh Penulis, 2020)

Berdasarkan dari visualisasi hasil word cloud dari akun media sosial @cityofgoldcoast (lihat Gambar. 3) menempatkan kata gold dan coast sebagai kata yang sering digunakan dalam setiap tweet. Secara sekilas dapat dilihat tagline \#ourgoldcoast menjadi salah satu kata yang memiliki visualisasi besar. Kata-kata lainnya yang memiliki visualisasi cukup besar diataranya day, city, today \#wearegoldcoast, greet, weekend, alerts dan kata lainnya. Namun secara stastik masing-masing kata yang telah tervisualisasi tersebut memiliki nilai sesuai dengan seberapa sering kalimat tersebut muncul dalam tweet.
Indonesia dalam acara Indonesia Innovation Award.

Selanjutnya penluis akan melihat sejauh mana akun @cityofgoldcoast dan @humasbdg menggunakan media sosial berdasarkan topik yang sering dibicarakan. Penulis menggunakan fitur word cloud yang terdapat pada Software NVivo 12 Plus. Word cloud masuk kepada kategori aplikasi tag word yang digunakan untuk mempelajari tentang jumlah dan jenis topik yang ada dalam tubuh teks (Heimerl, Lohmann, Lange, \& Ertl, 2014). Selain itu menggunakan tag cloud dengan tujuan menggambarkan konten teks yang berkembang seiring waktu (Cui et al., 2010). Biasanya, tinjauan umum statistik ini dicapai dengan secara positif mengkorelasikan ukuran font dari tag yang digambarkan dengan frekuensi kata (Heimerl et al., 2014). 
Tabel 1

Frekuensi Kata Akun @cityofgoldcoast

\begin{tabular}{lrr}
\hline Word & Length & Count \\
\hline Gold & 4 & 711 \\
Coast & 5 & 650 \\
City & 4 & 312 \\
\#ourgoldcoast & 13 & 307 \\
today & 5 & 287 \\
Day & 3 & 260 \\
Stay & 4 & 193 \\
Get & 3 & 191 \\
water & 5 & 173 \\
weekend & 7 & 170 \\
\#goldcoast & 10 & 163 \\
beach & 5 & 162 \\
\#wearegoldcoast & 15 & 158 \\
date & 4 & 155 \\
photo & 5 & 149 \\
check & 5 & 142 \\
affected & 8 & 137 \\
planned & 7 & 137 \\
streets & 7 & 137 \\
alerts & 6 & 136 \\
\hline Sumber:
\end{tabular}

Sumber: diolah oleh penulis, (2020)

Tabel. 1 menampilkan nilai masing-masing kata yang tervisualisasi dari akun @cityofgoldcoast. Dari 100 kata yang divisualisasi, penulis mengambil 20 kata terbesar yang menjadi topik pembicaraan. Penulis berpendapat akun @ cityofgoldcoast lebih fokus memberitakan terkait dengan kondisi aktual yang terjadi. Hal ini terlihat dari beberapa kata yang cocok untuk menjelaskan hal tersebut seperti today, water, date, streets, alerts. Kata weekend mengkonfirmasi bahwa akun @cityofgoldcoast akan lebih sering memberikan informasi melalui twitter pada saat kondisi liburan.
Tabel. 2 memperlihatkan frekuensi nilai daripada kata yang berasal dari tweet @humasbdg. Sama dengan akun @cityofgoldcoast, penulis juga mengambil 20 kata dengan frekuensi nilai tertinggi. Kata bandung, kota, wali, pemkot, dan agenda menjadi lima kata dengan frekuensi nilai kata terbesar. Hal tersebut mengambarkan bahwasanya akun twitter @humasbdg lebih fokus kepada agenda yang dilakuan oleh Pemerintah Kota Bandung. Selain itu terdapat kata oded dan Daniel yang merupakan nama dari Walikota Bandung, sehingga penulis berpendapat bahwasannya @humasbdg juga fokus dalam pemberitaan terkait denga walikota bandung. 
Tabel 2

Frekuensi Kata Akun@humasbdg

\begin{tabular}{lrr}
\hline Word & Length & Count \\
\hline bandung & 7 & 2179 \\
kota & 4 & 1958 \\
Wali & 4 & 564 \\
pemkot & 6 & 370 \\
agenda & 6 & 294 \\
balai & 5 & 274 \\
oded & 4 & 266 \\
cuaca & 5 & 169 \\
danial & 6 & 166 \\
prakiraan & 9 & 166 \\
pemerintah & 10 & 135 \\
warga & 5 & 113 \\
Foto & 4 & 107 \\
daerah & 6 & 97 \\
indonesia & 9 & 94 \\
Bdg & 3 & 89 \\
Kecamatan & 9 & 85 \\
Masyarakat & 10 & 84 \\
Acara & 5 & 82 \\
\#bandungnuurang209 & 18 & 79 \\
\hline
\end{tabular}

Sumber: diolah oleh penulis (2020)

Selain mentweet terkait denga agenda Pemerintah Kota Bandung dan agenda Walikota Bandung, akun @ humasbdg juga memberikan informasi terkait dengan hal lain seperti kondisi lalu lintas jalan raya, prakiraan cuaca. Hal tersebut terlihat pada tabel. 2 bahwa kata kemacetan, prakiraan dan cuaca masuk kedalam 20 kata dengan frekuensi nilai terbesar. Informasi terkait dengan kondisi masyarakat juga menjadi perhatian dari akun @humasbdg dengan masuknya kata masyarakat dan warga. Nampaknya akun @humasbdg tidak hanya menginformasikan terkit situasi lokal, melainkan kodisi nasional menjadi perhatian dengan masuknya kata
Indonesia.

Selanjutnya penulis melakukan cluster analysis terkait dengan akun @cityofgoldcoast dan @humasbdg dengan menggunakan fitur word similarity. Hal ini dilakukan guna memvisualisasikan pola dalam penelitian ini dengan mengelompokkan sumber dari berbagi kata yang mirip. Sehingga akan mempermudah untuk mengetahui pola sebaran informasi dari sebuah akun. Hal ini sekaligus akan memvisualisasiskan interksi yang dilakukan oleh akun tersebut. 


\section{Noken Vol.6 (No.1) Halaman: 75-90 Tahun}

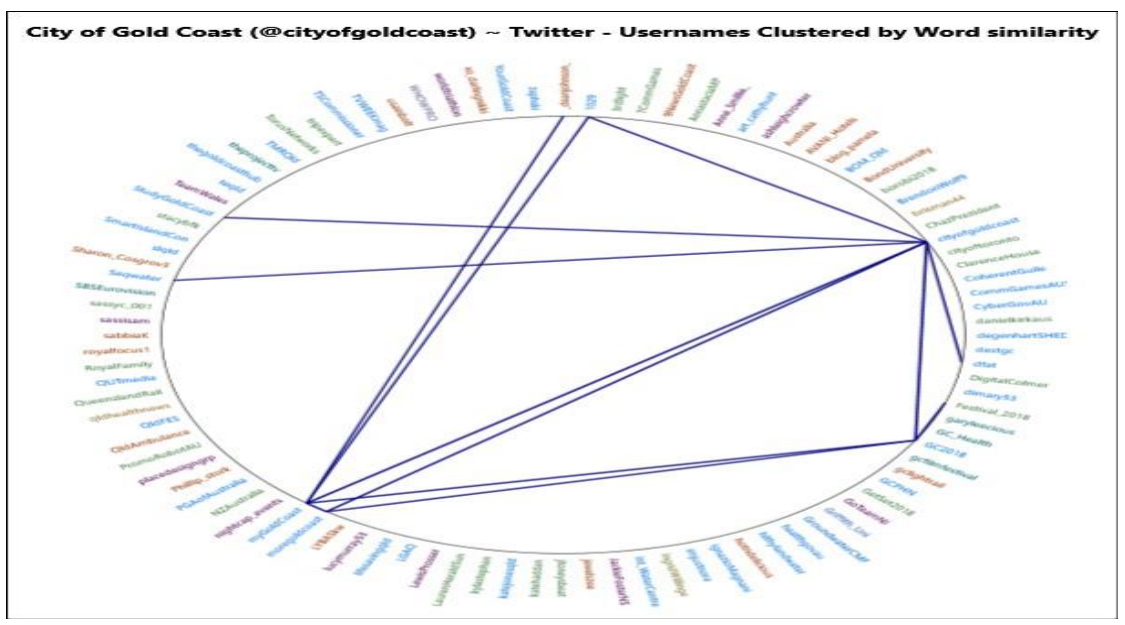

\section{Gambar 4}

Cluster Alayasis Akun @ cityofgoldcoast (diolah oleh penulis, 2020)

Berdasarkan hasil cluster diatas, akun @ cityofgold coast persebaran informasinya cenderung berinteraksi dengan akun lain yang juga merupakan bagian dari official Kota Gold Coast seperti akun untuk para pelajar di Kota Gold Coast (@studygoldcoast), akun untuk mempromosikan bisnis di Kota Gold Coast (@moregoldcoast), dan akun resmi dari pagelaran event olahraga antara negara persemakmuran yang dilaksanakan di Kota Gold Coast pada april 2019 lalu (@GC2018). Selain itu pesebaran informasi aku @cityofgoldcoast juga terhadap media lokal yaitu myGC.co.au yaitu_ (@mygoldcoast). Akun @ cityofgoldcoast juga berinterkasi dengan akun resmi Departemen Luar Negeri \& Perdagangan Australia (@dfat). Namun interaksi komunikasi yang dilakukan cenderung masih satu arah, hal ini didasarkan kepada rendahnya interaksi yang dilakukan akun @cityofgoldcoast kepada masyarakat. Akun @cityofgoldcoast lebih spesifik untuk mengupdate informasi yang telah di terbitkan di website resmi Majelis Kota Gold Coast.

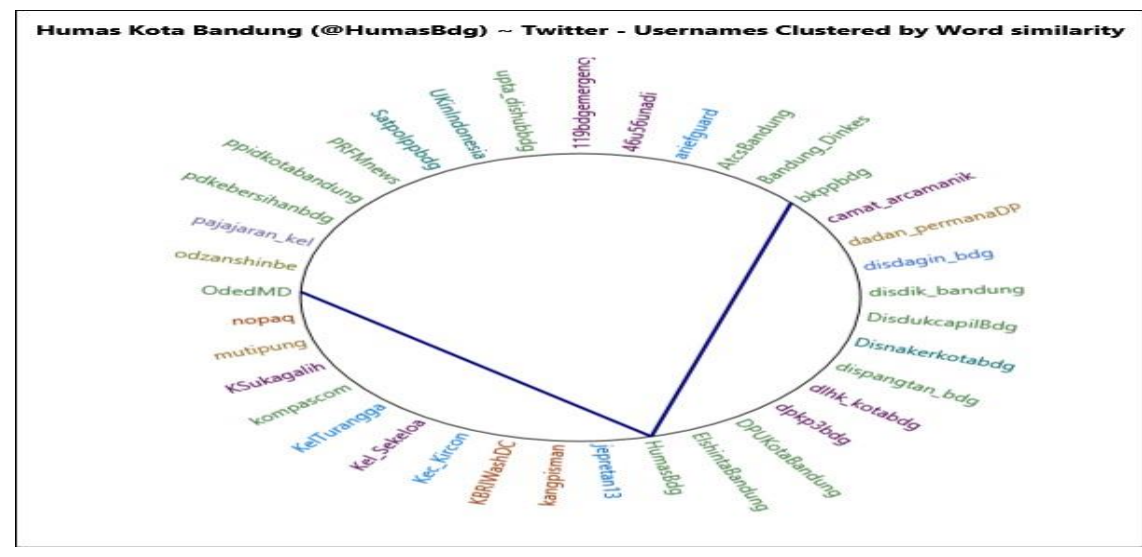

Gambar 5

Cluster Alayasis Akun@humasbdg (diolah oleh penulis, 2020) 
Akun @humasbdg justru mempunyai persebaran informasi yang lebih sedikit. Pesebaran informasi tersebut hanya menuju kepada akun resmi Walikota Bandung (@odedMD) dan akun resmi Badan Kepegawaian, Pendidikan, dan Pelatihan Kota Bandung (@bkppbdg). Pola interaksi yang dilakukan hanya sebatas kepada instansi-instansi pemerintah saja. Hal ini tentu saja menjadi catatan bagi akun @humasbdg untuk menggunakan media sosial sebagai wadah interaksi.

Berdasarkan analisis intensitas tweet ada kesamaan dalam memberikan informasi yang dilakukan oleh kedua akun twitter miliki pemerintah tersebut. Dalam memberikan informasi @cityofgoldcoasat dan @humasbdg menghubungkan tweet dengan website pemerintah. Informasi yang diberikan oleh @cityofgoldcoast maupun @humasbdg hanya informasi singakat, untuk mendapatkan lebih lengkap masyarakat harus mengakses website terlebih dahulu. Penulis berpendapat bahwasanya hal ini dapat memaksimalakan saluran informasi yang dimiliki pemerintah. Namun, disatu sisi dengan menghubungkan kepada saluran informasi lainnya dapat memperlambat penyaluran informasi yang diberikan.

Karakteristik media sosial yang cenderung instan dalam memperoleh informasi menjadi alasan mengapa masyarakan cenderung lebih tertarik mengakses informasi lewat sosial media. Namun ketika masyarakat harus mengakses informasi mengharuskan masuk dalam website pemerintah, justru akan mengurangi partisipasi masyarakat. Pada dasarnya keterlibatan masyarakat pada platform media sosial memungkinan untuk pemerintah untuk memanfaatkan sebagai dasar kebijakan (Charalabidis et al., 2014; Mehmet, D'Alessandro, Pawsey, \& Nayeem, 2018). Hal ini mungkin menjadi catatan untuk akun @cityofgoldcoast maupun akun @humasbdg. Namun poin baiknya adalah Majelis Kota Gold Coast dan Pemerintah Kota Banding telah masuk kepada tahap yang benar sebagai sebuah kota dengan konsep smart city. Pada dasarnya kota denga konsep smart city harus dapat mengambil manfaat dari keterlibatan warga melalui crowdsourcing dan media sosial (Witanto et al., 2018), dan ini telah dilakukan oleh kedua kota tersebut. Penulis melihat bahwa masingmasing akun mencoba untuk mengikuti pola kebiasaan yang dilakukan oleh masyarakat setempat. Seperti akun @ cityofgoldcoast mengetweet terkait dengan kebiasaan masyarakatnya untuk keluar rumah pada saat weekend dan liburan. Begitupula dengan @humasbdg, dengan karakteristik bandung sebagai kota besar membuat kemacetan sebagai salah satu kendala. Apa yang dilakukan oleh kedua akun pemerintah tersebut sejalan dengan pendapat dari Clarke (2017) bahwa medi sosial juga mampu untuk meningkatkan minat dalam perilaku ekonomi atau memberikan "dorongan" untuk mengatasi masalah sosial dan pemasaran.

Pada analisis menggunakan word cloud topik pembicaraan daripada akun @humasbdg, terkait dengan kondisi lalulintas serupa dengan yang dilakukan oleh otoritas berwenang di Mexico (Alsonosy et al., 2018). Hal ini sejalan dengan pendapat Anson et al., (2017) yang menyatakan bahwa media sosial memberikan aktor kesempatan untuk memahami efektivitas komunikasi 
kesiapsiagaan mereka di media sosial. Penulis berpendapat Baik Majelis Kota Gold Coast maupun Pemerintah Kota Bandung telah memiliki keunggula ketika memberikan pelayanan menggunakan media sosial. Hal ini didasrkan kepada pendapat Brandt, Bendler, \& Neumann (2017) bahwa analisis media sosial mampu untuk menangkap pola spasial di dalam kota yang terkait dengan keberadaan pengguna dan keterlibatan lingkungan berdasarkan dengan topik pembahsan.

Pada analisis cluster kedua akun baik @cityofgoldcoast maupun @humasbdg memiliki pola interkasi dan komunikasi yang lemah kepada masyarakat. Padahal Clarke \& Margetts (2014) berpendapat pada dasarnya media sosial memungkinkan untuk melakukan interaksi secara realtime anatar pemerintah dan masyarakat. Clarke (2017) juga menekankan bahwa medi sosial juga mampu untuk meningkatkan minat dalam perilaku ekonomi atau memberikan "dorongan" untuk mengatasi masalah sosial dan pemasaran. Hal ini harus bisa diadopsi oleh kedua akun pemerintah baik @cityofgoldcoast milik Majelis Kota Gold Coas maupun @humasbdg milik Pemerintah Kota Bandung. Kedua akun tersebut memiliki kekuranag dalam berinteraksi dengan masyarakat. Penulis berpendapat bahwasanya idealnya komunikasi yang dilakukan di medi sosial adalah dengan dua arah. Hal itu memungkinkan kedua aktor yang terlibat akan saling bertukar informasi, baik pemerintah kepada masyarakat ataupun sebaliknya. Hal ini selaras dengan yang dikatakan oleh Nabatchi (2012) berkaitan dengan komunikasi public, ia mengatakan bahwa komunikasi dua arah memfasilitasi kedua aktor untuk menjadi pemberi maupun menerima informasi. Lee \& Hoon (2012) juga dalam tulisannya mengatakan bahwasanya two-ways communication merupakan model komunikasi public yang paling ideal. Sebaran informasi juga idelanya tidak terbatas kepada akun pemerintah lainnya. Lebih bagus rasanya sebaran informasi juga menyetuh lapisan masyarakat hinga mendasar. Hal ini dapat menjadi catatan untuk penelitian selanjutnya terkait dengan pola interaksi akun resmi pemerintah terhadap partisipasi masyarakat di media sosial.

\section{SIMPULAN}

Pada dasarnya usaha yang dilakukan oleh Majelis Kota Gold Coast maupun Pemerintah Kota Bandung merupakan salah satu cara yang tepat di era disturbsi hari ini. Dengan memanfaatkan teknologi informasi dan komunikasi yang terus mengalamin perkembangan, nampaknya memang mengharuskan pemerintah untuk terjuan di dunia daring. Terlebih media sosial yang setiap saat mengalamin peningkatan penggunan. Namun, kedua kota tersebut telah pantas dikatakan sebagai smart city, karena telah mnggunakan media sosial sebagai pelayanan. Selain itu keduanya dalam pemberian informasi mencoba untuk menyesuaikan karakteristik masing-masing masyarakat.

Berdasarkan hasil analisis berdasarkan intensitas tweet, terdapat kesamaan dalam memberikan informasi yang dilakukan oleh dua akun Twitter yang dimiliki oleh pemerintah. Dalam memberikan informasi @ cityofgoldcoasat dan @ humasbdg yang menghubungkan tweet dengan situs web 
pemerintah. Informasi yang diberikan oleh @cityofgoldcoast atau@humasbdg hanya informasi singkat, untuk mendapatkan lebih lengkap masyarakat harus mengakses situs web terlebih dahulu. Kemudahan pemeberian informasi nampakanya harus mendaptkan perbaikan informasi, baik @humasbdg maupun @cityofgoldcoast. Nantinya, hal ini akan berpengaruh terhadap partisipasi masyarakat.

Hasil analisis menggunakan word cloud menyatakan kedua akun pemerintah tersebut memiliki topik pembahasan yang berbeda. Akun@cityofgoldcoast memberikan informasi actual yang sedang terjadi, selain itu informasi terkait akhir pecan dan liburan menjadi salah satu topik utama akun ini. Sedangankan @humasbdg arah informasinya conodong kepada seputar keprotokolan yang dilakukan oleh Pemerintah Kota Bandung maupun Walikota Bandung serta informasi terkinin terkait kondisi jalan raya. Hal ini menjadi keinggulan bagi keduannya karena telah memanfaatkan media sosial sebagai media analisis.

Cluster analysis memvisualisasikan terkait dengan pola persebaran informasi yang dilakukan oleh kedua akun tersebut. Hasil pesebaran informasi dari akun @ cityofgoldcoast cenderung mengarah kepada dengan akun lain yang juga merupakan bagian dari official Kota Gold Coast. Berbeda dengan akun @humasbdg cenderung lebih sempit dengan persebaran hanya kepa akun resmi miliki Walikota bandung dan milik Badan Kepegawaian, Pendidikan, dan Pelatihan Kota Bandung. Akan tetapi pola interaksi yang dilakukan oleh kedua akun ini sama kurang berinterkasi kepada masyarakat. Hal ini akan berpengaruh kepada tingkat partisipasi masyarakat di media sosial. Idealnya keduanya menggunakan pola komunikasi dua arah, namun dalam implementasinya hanya berinterkasi dengan satu arah.

\section{DAFTAR PUSTAKA}

Alizadeh, T., \& Irajifa, L. (2018). Gold Coast smart city strategy: informed by local planning priorities and international smart city best practices Tooran Alizadeh * Leila Irajifar. 9(2), 153-173.

Alkhatib, M., El Barachi, M., \& Shaalan, K. (2019). An Arabic social media based framework for incidents and events monitoring in smart cities. Journal of Cleaner Production, 220, 771-785.

https://doi.org/10.1016/j.jclepro.2019. 02.063

Alsonosy, O., Rady, S., Badr, N., \& Hashem, M. (2018). Business Behavior Predictions Using Location Based Social Networks in Smart Cities. Information Innovation Technology in Smart Cities, pp, 105122.

Anson, S., Watson, H., Wadhwa, K., \& Metz, K. (2017). Analysing social media data for disaster preparedness: Understanding the opportunities and barriers faced by humanitarian actors. International Journal of Disaster Risk Reduction, 21, 131-139. https://doi.org/10.1016/j.ijdrr.2016.11 .014

Belkahla Driss, O., Mellouli, S., \& Trabelsi, Z. (2019). From citizens to government policy-makers: Social media data analysis. Government Information Quarterly, 36(3), 560570. https://doi.org/10.1016/j.giq.2019.05. 002 
Bhatti, A., Arif, S., Mehar, M., \& Younas, S. (2018). Impact of Social media brand communication on Brand Knowledge: Mediating role of Brand Image \& Brand Awareness Application of CBBE model theory of Keller. Journal of Management Info, 4(4), 12-18. https://doi.org/10.31580/jmi.v15i1.72

Birjali, M., Beni-Hssane, A., \& Erritali, M. (2017). Analyzing Social Media through Big Data using InfoSphere BigInsights and Apache Flume. Procedia Computer Science, 113, 280-285.

https://doi.org/10.1016/j.procs.2017.0 8.299

Brandt, T., Bendler, J., \& Neumann, D. (2017). Social media analytics and value creation in urban smart tourism ecosystems. Information and Management, 54(6), 703-713. https://doi.org/10.1016/j.im.2017.01.0 04

Charalabidis, Y., Loukis, E. N., Androutsopoulou, A., Karkaletsis, V., \& Triantafillou, A. (2014). Passive crowdsourcing in government using social media. Transforming Government: People, Process and Policy, 8(2), 283-308. https://doi.org/10.1108/TG-09-20130035

Clarke, A. (2017). The vestiges and vanguards of policy design in a digital context. 60(4), 476-497. https://doi.org/10.1111/capa.12228

Clarke, A., \& Margetts, H. (2014).

Governments and citizens getting to know each other? open, closed, and big data in public management reform. Policy and Internet, 6(4), 393-417. https://doi.org/10.1002/19442866.POI377
Criado, J. I., Sandoval-Almazan, R., \& GilGarcia, J. R. (2013). Government innovation through social media. Government Information Quarterly, 30(4), 319-326. https://doi.org/10.1016/j.giq.2013.10. 003

Cui, W., Wu, Y., Liu, S., Wei, F., Zhou, M., \& Qu, H. (2010). Contextpreserving, dynamic word cloud visualization. IEEE Computer Graphics and Applications, 30(6), 42-53. https://doi.org/10.1109/MCG.2010.10 2

Desdemoustier, J., Crutzen, N., \& Giffinger, R. (2019). Municipalities' understanding of the Smart City concept: An exploratory analysis in Belgium. Technological Forecasting and Social Change, 142(October), 129-141. https://doi.org/10.1016/j.techfore.201 8.10 .029

Dhingra, M., \& Chattopadhyay, S. (2016). Advancing smartness of traditional settlements-case analysis of Indian and Arab old cities. International Journal of Sustainable Built Environment, 5(2), 549-563. https://doi.org/10.1016/j.ijsbe.2016.08 .004

Gintova, M. (2019). Understanding government social media users: an analysis of interactions on Immigration, Refugees and Citizenship Canada Twitter and Facebook. Government Information Quarterly, (December 2018), 101388. https://doi.org/10.1016/j.giq.2019.06. 005

Gold Coast City Council. (2018). City of Gold Coast Local Disaster Management Plan. (November).

Gunawong, P. (2014). Open Government 
and Social Media: A Focus on

Transparency. Social Science

Computer Review, 1-12.

https://doi.org/10.1177/08944393145

60685

Heimerl, F., Lohmann, S., Lange, S., \& Ertl, T. (2014). Word cloud explorer: Text analytics based on word clouds. Proceedings of the Annual Hawaii International Conference on System Sciences, 1833-1842. https://doi.org/10.1109/HICSS.2014.2 31

Lee, G., \& Hoon, Y. (2012). An Open Government Maturity Model for social media-based public engagement. Government Information Quarterly, 29(4), 492-503. https://doi.org/10.1016/j.giq.2012.06. 001

Lu, X., \& Brelsford, C. (2014). Network structure and community evolution on Twitter: Human behavior change in response to the 2011 Japanese earthquake and tsunami. Scientific Reports, 4, 1-11. https://doi.org/10.1038/srep06773

Magro, M. J. (2013). A Review of Social Media Use in E-Government. Administrative Sciences, 2(December), 148-161. https://doi.org/10.3390/admsci202014 8

Mehmet, M. I., D’Alessandro, S., Pawsey, N., \& Nayeem, T. (2018). The national, regional and city divide: Social media analysis of stakeholders views regarding biological controls. The public reaction to the carp control herpes virus in Australia. Journal of Environmental Management, 227(March), 181-188. https://doi.org/10.1016/j.jenvman.201 8.08.093

Moreno-Ibarra, M., \& Torres-Ruiz, M.
(2019). Civic participation in smart cities. In Smart Cities: Issues and Challenges. https://doi.org/10.1016/b978-0-12816639-0.00003-x

Nabatchi, T. (2012). Putting the "Public" Back in Public Values Research: Designing Participation to Identify and Respond to Values. Public Administration Review, 72(5), 699708. https://doi.org/10.1111/j.15406210.2012.02544.x

Nilamsari, N. (2014). Memahami Studi Dokumen Dalam Penelitian Kualitatif. Jurnal Wacana. Diakses Pada Hari Selasa 2 April 2019. Pukul 20:30 WIB, 14(2), 177-181. Retrieved from 143-455-1-PB (1).pdf

Nurmandi, A., Almarez, D., Roengtam, S., Salahudin, Jovita, H. D., Kusuma Dewi, D. S., \& Efendi, D. (2018). To what extent is social media used in city government policy making? Case studies in three asean cities. Public Policy and Administration, 17(4), 600-618. https://doi.org/10.13165/VPA-18-174-08

Sáez-Martín, A., Haro-de-Rosario, A., \& Caba-Perez, C. (2014). A vision of social media in the Spanish smartest cities. Transforming Government: People, Process and Policy, 8(4), 521-544. https://doi.org/10.1108/TG03-2014-0010

Susanto, E. H. (2017). Media Sosial Sebagai Pendukung Jaringan Komunikasi Politik. Jurnal ASPIKOM, 3(3), 379. https://doi.org/10.24329/aspikom.v3i3 .123

Walidin, W., Idris, S., \& Tabrani ZA. (2015). Metodologi Penelitian Kualitatif \& Grounded Theory (Pertama; Masbur, R. Murziqin, \& K. 
Halim, eds.). Retrieved from https://repository.arraniry.ac.id/id/eprint/1301/1/Full Buku MP Kualitatif \%26 Grounded Theory.pdf

Witanto, J. N., Lim, H., \& Atiquzzaman, M. (2018). Smart government framework with geo-crowdsourcing and social media analysis. Future Generation Computer Systems, 89, 19.

https://doi.org/10.1016/j.future.2018.0 6.019

\section{PROFIL SINGKAT}

Penulis Pertama Tengku Imam Syarifuddin, S. IP merupakan mahasiswa Magister Ilmu Pemerintahan Universitas Muhammadiyah Yogyakarta. Penulis menempuh pendidikan strata satu pada Program Studi S1 Pemerintahan Integratif Universitas Mulawarman. Penulis memiliki minat kajian pada bidang pemerintahan desa, media sosial, dan kebijakan publik.

Penulis kedua Eko Priyo Purnomo, M.Res., Ph.D merupakan dosen Magister Ilmu Pemerintahan dan S1 Program Studi Ilmu Pemerintahan Universitas Muhammadiyah Yogyakarta. Riwayat Pendidikan Penulis yaitu S1 Ilmu Pemerintahan Universitah Gadjah Mada, S2 Ilmu Politik Universitas Gadjah Mada, S2ng Research di University of Leeds dalam bidang Sustainability dan S3 Politik Lingkungan dan Kebijakan Publik, University of Bradford United Kingdom. Saat ini juga peneliti Utama di Jusuf Kalla School of Government dan peneliti tamu di beberapa kampus Luar Negeri seperti di Korea Universitas, Cambridge dll.
Penulis ketiga Budiman S. IP., M. Si merupakan Dosen Ilmu Pemerintahan Universitas Mulawarman, Kalimantan Timur. Riwayat pendidikan Penulis S1 Ilmu Pemerintahan Universitas Hasanuddin Makassar, S2 Administrasi Pembangunan Unversitas Hasanuddin Makassar. Penulis memiliki minat kajian pada bidang politik lokal dan birokrasi.

Penulis keempat A. Andika Yasa Mahasiswa Magister Ilmu Pemerintahan Universitas Muhammadiyah Yogyakarta. Penulis menempuh jenjang strata satu pada Program Studi Ilmu Pemerintahan Universitas Muhammadiyah Yogyakarta. Memiliki minat kajian pada bidang media sosial dan korupsi. 